\title{
Krzyż - ołtarz - orientacja zanoszonych modlitw
}

Przyglądając się papieskiemu ołtarzowi w bazylice św. Piotra na Wzgórzu Watykańskim w Rzymie i porównując go z wieloma ołtarzami w naszym kraju, nie sposób nie dostrzec znaczącej różnicy. Papieski ołtarz podczas sprawowania Eucharystii ma krzyż i kandelabry. Krzyż i kandelabry zostają na ołtarzu także po mszy świętej. Czy tak usytuowany krzyż to nowość? Czy mamy do czynienia z nowością według magisterium papieża Benedykta XVI?

Posoborowe Ogólne wprowadzenie do Mszału Rzymskiego uczy, że na ołtarzu, który jest także stołem, ,pod sakramentalnymi znakami uobecnia się ofiara krzyża" (nr 296), zaś na samym ołtarzu lub obok niego ma być umieszczony krzyż z wizerunkiem Ukrzyżowanego. Ma on być widoczny dla zgromadzonych wiernych podczas celebracji i ma pozostać na ołtarzu poza czasem sprawowanej liturgii (por. nr 308$)^{1}$. Można więc powiedzieć, że papież nie wprowadził żadnej nowości, która by nie była znana myśli posoborowej. Skąd więc współczesna dyskusja wokół krzyża na papieskim ołtarzu?

Gdy Kościół katolicki, a z nim cały świat świętował jubileusz dwutysięcznej rocznicy narodzin Jezusa Chrystusa z Nazaretu, a zarazem kończył drugie i wkraczał w nowe trzecie tysiąclecie swojego istnienia, Joseph kard. Ratzinger, ówczesny prefekt Kongregacji Nauki Wiary, opublikował książkę Duch liturgii. W niej to wśród wielu zagadnień, takich jak istota liturgii czy czas i przestrzeń w liturgii, znajdujemy zapis mówiący o ołtarzu, kierunku modlitwy i krzyżu na mensie ołtarzowej. Swoje rozważania o tych zagadnieniach Ratzinger kończy przypomnieniem,

${ }^{1}$ Por. Ogólne wprowadzenie do Mszału Rzymskiego. Z trzeciego wydania mszału rzymskiego Rzym 2002, Poznań 2004, s. 83, 85. 
że w świadomości teologicznej Kościoła wschód był łączony ze znakiem Syna Bożego - krzyżem, jak i z powtórnym przyjściem Chrystusa. Jeśli modląca się wspólnota nie może zwrócić się ku wschodowi, znak krzyża staje się duchowym wschodem. Ratzinger mówi wprost: „Powinien on stać na środku ołtarza oraz być punktem skupiającym wzrok kapłana i modlącego się zgromadzenia"'. Od pewnego czasu, precyzyjnie ujmując od 2007 roku, podczas celebracji Eucharystii, której przewodniczy Benedykt XVI, krzyż właśnie w ten sposób jest umieszczony na mensie ołtarzowej3. Tym samym zostało wskazane, że miejsce celebrowania Eucharystii, a zarazem jej tajemnicę należy odczytywać w triadzie: stół, ołtarz i krzyż .

\section{Pochodzenie drzewa krzyża}

Papież Benedykt XVI podczas swojej pielgrzymki na Cypr 5 czerwca 2010 roku w homilii Krzyż daje światu nieskończoną nadzieję wygłoszonej w kościele Świętego Krzyża w Nikozji przypominał o starej tradycji mówiącej, że drzewo, z którego pochodzi krzyż Jezusa Chrystusa, zostało zasiane przez Seta, syna Adama - protoplasty rodu ludzkiego. Krzyż Jezusa Chrystusa postawiony na Golgocie jest usytuowany w miejscu, gdzie Set dokonał tego zasiewu. Nasienie tego szczególnego drzewa pochodziło z ogrodu Eden, z drzewa dobra i zła. Papież puentuje, że „zrządzeniem Bożej Opatrzności dzieło szatana miało zostać zwyciężone za pomocą jego własnej broni”’

\section{Krzyż narzędziem okrutnej śmierci}

Znak krzyża i wydarzenie ukrzyżowania Jezusa Chrystusa są wspominane częściej w Nowym Testamencie niż ustanowienie Najświętszego

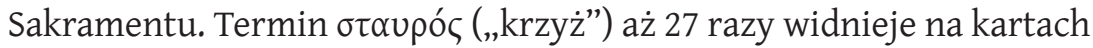
Nowego Testamentu. We wszystkich przypadkach termin ten opisuje wzniesiony pal, który w czasach rzymskich był narzędziem kaźni i zagła-

${ }^{2}$ J. Ratzinger, Duch liturgii, tłum. E. Pieciul, Poznań 2002, s. 77.

${ }^{3}$ Pod koniec 2007 roku doszło do zmiany na stanowisku mistrza ceremonii papieskich. Ks. Guido Marini zastąpił bpa Piera Mariniego.

${ }^{4}$ Por. J. Ratzinger, Duch liturgii, dz. cyt., s. 69-77.

${ }^{5}$ Benedykt XVI, Krzyż daje światu nieskończona nadzieję, „L'Osservatore Romano” wydanie polskie 31 (2010) nr 8-9, s. 14. 
dy. Narzędzie to składało się z dwóch belek. Nie były one skrzyżowane, ale na pionowej umieszczona była belka pozioma, co tworzyło tzw. crux commissa w kształcie litery T (tau). Skazaniec niósł na miejsce stracenia belkę poziomą (supplicium) ${ }^{6}$. Kara ukrzyżowania znana w czasach antycznych na Środkowym Wschodzie została wprowadzona na obszarze basenu śródziemnomorskiego w czasie wojen punickich, a została zniesiona dopiero przez cesarza Konstantyna Wielkiego w 320 roku. Powodem zaniechania wykonywania kary śmierci przez ukrzyżowanie było właśnie to, że w ten sposób pozbawiono życia Jezusa Chrystusa

\section{Znak krzyża - początki}

Najstarsze wyznanie wiary wierzących w Zmartwychwstałego pochodzi z Dziejów Apostolskich (Dz 3, 13-15; 4, 8-12; 5, 29-32; 8, 30-35; 10,40). Tę fundamentalną chrześcijańską prawdę wiary można zawrzeć w słowach: „Ten Jezus, który został zabity, żyje”. Nie dziwi więc, że wśród świadectw pierwszych chrześcijan znajdujemy znak krzyża jako wyraz życia ze Zmartwychwstałym.

Archeolog Joseph Wilpert na podstawie znalezisk w katakumbach dolicza się około 20 krzyży narysowanych lub namalowanych na grobach. W połowie II wieku na podziemnych grobowcach pojawia sięjako pierwszy krzyż grecki, a następnie łaciński. Z III wieku pochodzi znak potrójnie powtórzonego krzyża greckiego, a w jednym z tuneli katakumb Domicyli znajduje się płyta marmurowa, na której widać palmę, krzyż i imię zmarłej osoby. Jest to krzyż łaciński. Niemiecki archeolog w tej kompozycji dopatruje się zapisu zwycięstwa. Zmarła osoba otrzymuje palmę zwycięstwa po tym, jak dźwigała krzyż za swego życia. Z pierwszych wieków pochodzą również łacińskie krzyże, obok których z prawej i lewej strony są wypisane greckie litery „A" i „,” oraz różne formy kotwicy uformowanej na krzyżu bez żadnej ornamentyki bądź

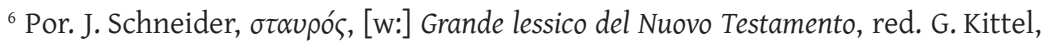
G. Friedrich, edizione italiana a cura di F. Montagnini, G. Scarpat, O. Soffritti, t. 12, Brescia 1979, kol. 974.

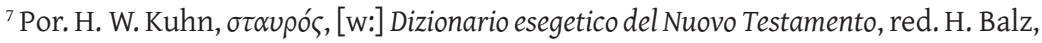
G. Schneider, t. 2, Brescia 1998, kol. 1397. 
z dwoma rybami ${ }^{8}$.Zdaniem archeologa z czasem nastąpiła transformacja kotwicy w krzyż i literę „T” nazywaną przez Tertuliana species crucis9.

Tertulian podaje, że "gdy udajemy się w podróź lub jesteśmy w drodze, kiedy wchodzimy lub wychodzimy, gdy prosimy o jałmużnę, gdy wstajemy, gdy siadamy do stołu, gdy zapalamy światło, gdy udajemy się na spoczynek, gdy siadamy na fotelu, cokolwiek czynimy w życiu każdego dnia, znaczymy się wówczas znakiem krzyża"10. Mówi on także, że wśród obrzędów wyjaśniających sprawowanych dla tych, którzy właśnie otrzymali chrzest, jest znaczenie czoła neofity znakiem krzyża ${ }^{11}$.

Cyryl Jerozolimski w swojej katechezie uczy: „Ufnie uczyńmy znak krzyża palcami na czole i na wszystkim chlebie, który spożywamy, na kielichu, który pijemy, przy wejściu i wyjściu, przed snem, kładąc się na spoczynek, przy wstawaniu, chodzeniu i spoczynku! Jest on wielką obroną. Nie muszą za niego płacić ubodzy, trudzić się słabi. Od Boga jest dany jako łaska. Krzyżjest znakiem wierzących, postrachem szatanów"12.

Ambroży z Mediolanu mówi o sakramencie chrztu: „Otrzymujesz sakrament Krzyża, ponieważ Chrystus zawisł na krzyżu, a Jego ciało zostało przebite gwoździami. Ty więc jesteś ukrzyżowany, połączony z Chrystusem, przytrzymują cię gwoździe Pana naszego Jezusa Chrystusa, aby szatan nie mógł ciebie oderwać"13. Dla biskupa z Mediolanu sakrament chrztu to sakrament krzyża.

Kanony Hipolita w wersji arabskiej, pochodzące najprawdopodobniej z patriarchatu aleksandryjskiego, mówią, że wierni podczas liturgii „znaczą swe czoło znakiem krzyża, znakiem zwycięstwa nad szatanem

${ }^{8}$ Por.J. Wilpert, La croce suimonumenti delle catacombe, „Nuovo Bullettino di Archeologia Cristiana" 8 (1902) nr 1-2, s. 5-14.

${ }^{9}$ Por. tamże, s. 14.

${ }^{10}$ Cyt za: J. Lescrauwaet, Paradoksalny charakter krzyża, „Communio. Międzynarodowy Przegląd Teologiczny" 4 (1984) nr 1, s. 54.

${ }^{11}$ Por. C. Krakowiak, Katechumenat chrzcielny dorosłych $w$ Kościele posoborowym, Lublin 2003, s. 53-54.

${ }^{12}$ Cyryl Jerozolimski, Katechezy przedchrzcielne i mistagogiczne, tłum. W. Kania, opatrzył wstępem J. Bojarski, oprac. M. Bogucki, Kraków 2000, s. 204 (Biblioteka Ojców Kościoła, 14).

${ }^{13}$ Św. Ambroży z Mediolanu, Wyjaśnienie symbolu. O tajemnicach. O sakramentach, Kraków 2004, s. 78 (Źródła Myśli Teologicznej, 31). 
i znakiem chwały"14. Ile razy tak czyniono? Same kanony nic nie mówią także o przygotowaniu, udekorowaniu ołtarza, a jedynie o higienie, jaka ma panować w Świętym Przybytku, gdzie jest ołtarz; o przygotowaniu na nim darów do składania Najświętszej Ofiary, o tym, że obecni w Przybytku mają przyklękać i składać pokłony w kierunku ołtarza ${ }^{15}$.

W liturgii rzymskiej msza święta według Ordo Romanus I rozpoczynała się od uroczystej procesji, pozdrowienia ołtarza pokłonem i uczynienia znaku krzyża, który to papież robił kciukiem na czole ${ }^{16}$.

Oprócz grobów od II wieku namalowany krzyż pojawia się na niektórych frontonach chrześcijańskich domów. W ten sposób wskazywał mieszkańcom, gdzie jest wschód - kierunek zanoszonych przez nich modlitw. Natomiast od początku IV wieku, po tym jak cesarz Konstantyn otrzymał wizję krzyża, a cesarzowa Helena odnalazła relikwie krzyża świętego w Jerozolimie, zaczęto robić różne kopie krzyża: były one malowane lub mozaikowe, ale bez wizerunku ukrzyżowanego Jezusa Chrystusa. Sam zaś krzyżstał się znakiem zwycięstwa i był dekorowany żelazem, diamentami czy elementami roślinnymi - wówczas oznaczał drzewo życia ${ }^{17}$.

\section{Krzyż ołtarzem i znak krzyża na ołtarzu}

W czasach patrystycznych powstało także przeświadczenie, że krzyż Chrystusa stał się ołtarzem. Jan Chryzostom w homilii o krzyżu i łotrze mówi: „Chrystus raz ofiarowany do wzięcia na siebie grzechów wielu, zjawi się oczekującym Go na zbawienie. Oto tu został ofiarowany, a tam sam siebie ofiarował. Czy widziałeś, jak stał się i ofiarą, i ofiarnikiem, a ołtarz był krzyżem”"18. Ojciec ten w innym swoim dziele dodaje: „Na świętym ołtarzu nie tylko spoczywa Ciało Pańskie, ale na nim również

${ }^{14}$ Kanony Hipolita (wersja arabska), [w:] Kanony Ojców Greckich (tekst grecki i polski) Atanazego i Hipolita (tekst arabski i polski), przekł. S. Kalinkowski, J. Szymańczak, M. Mucha, Kraków 2009, s. 195* (Synody i Kolekcje Praw, 3).

${ }^{15}$ Por. Kanony Hipolita (wersja arabska), dz. cyt., s. 194*.

${ }^{16}$ Por. A. J. Nowowiejski, Msza święta, cz. 1, Warszawa 2001, s. 160-161; V. Raffa, Liturgia eucaristica. Mistagogia della Messa: dalla storia e dalla teologia alla pastorale pratica, Roma 1998, s. 219 (Bibliotheca „Ephemerides liturgicae”. Subsidia, 100).

${ }^{17}$ Por. J. Lescrauwaet, Paradoksalny charakter krzyża, dz. cyt., s. 55-56.

18 Św. Jan Złotousty, Dwadzieścia homilij i mów, tłum. T. Sinko, Kraków 1947, s. 163 (Złoty Wiek Myśli Chrześcijańskiej). 
stoi krzyż, który figuruje na wszystkich chrześcijańskich sprzętach i czynnościach"19.

\section{Orientacja modlitwy}

W czasach antycznych pogańskie świątynie zazwyczaj budowano na osi zachód-wschód, a ich fasady często były zorientowane ku wschodowi. W starożytnym Rzymie świątynia Jowisza wzniesiona na Kapitolu wyznaczała kierunek zanoszonych modlitw. Czy ta reguła dotyczyła miejsc poza Rzymem? Prawdopodobnie powszechnie nie obowiązywała ${ }^{20}$.

Tradycja chrześcijańska sprzed 190 roku nie podaje żadnych wskazówek co do ukierunkowania modlitwy. Ale już w III wieku Tertulian (Afryka Północna), Klemens z Aleksandrii i Orygenes (Egipt), Martyrium Pauli (Azja Mniejsza) i Didascalia apostolorum (Syria) informują o zanoszeniu modlitwy ku wschodowi. Współczesny badacz tego tematu prof. Martin Wallraff z Bonn podkreśla: „Korzenie tego zwyczaju są bardzo antyczne, ale co do niego nie zostaje nam nic innego, jak tylko niejasne poszlaki" ${ }^{21}$. Zauważa on, że chociaż interpretacja chrystologiczna niektórych perykop Pisma Świętego dokonana przez ojców Kościoła jest przekonująca co do ukierunkowania modlitwy ku wschodowi prawdopodobnie jako opis zachowań chrześcijan (modlitwa wspólnotowa i indywidualna ku wschodowi, przyrzeczenia chrzcielne wypowiadane przez katechumenów ku wschodowi, często grzebanie twarzą ku wschodowi, budowanie pierwszych kościołów na osi wschód-zachód), to mimo to ta chrześcijańska świadomość, jak i tak wczesna praktyka nie prowadzą do zidentyfikowania korzeni historycznych tego zjawiska. Nie ma pewności skąd się wzięło to ukierunkowanie modlitwy ku wschodowi ${ }^{22}$.

${ }^{19}$ Cyt za: S. Longosz, Nazwy ołtarza chrześcijańskiego, „Vox Patrum” 27 (2007) nr 50-51, s. 514.

${ }^{20}$ Por. M. Wallraff, La preghiera verso oriente alle origini di un uso liturgico, [w:] La preghiera nel tardo antico. Dalle origini ad Agostino. XXVII Incontro di studiosi dell'antichità cristiana. Roma, 7-9 maggio 1998, Roma 1999, s. 463-469 (Studia Ephemeridis Augustianum, 66).

${ }^{21}$ Tamże, s. 464.

${ }^{22}$ Por. tamże, s. 463-465. 


\section{Ołtarze, ich orientacja i krzyż}

Pierwsze prowizoryczne ołtarze chrześcijan nie miały krzyża. Były to czworonożne stoły-ławy w domus ecclesie czy też antyczne trzynożne taborety (trybadiony), które wygodnie można było wnosić i ustawiać w wąskich chodnikach w katakumbach ${ }^{23}$. Wówczas ława czy taboret stawały się ołtarzem poprzez fakt składania na nich ofiary Jezusa Chrystusa, a nie z racji jakiegoś specjalnego ich wytwarzania dla liturgicznych celów.

Pierwsze kościoły syryjskie przypominają „chrześcijańską wersję synagogi żydowskiej" ${ }^{24}$. Z bemy znajdującej się w centrum nawy zanoszono modlitwy i czytano odpowiednie lektury. We wschodniej części bemy była zasłona, za którą znajdowała się arka. Po przeciwnej stronie bemy (zachodniej) była katedra biskupa z miejscami dla prezbiterów. Kierunkiem modlitwy całego zgromadzenia był geograficzny wschód. W apsydzie kościoła usytuowanej we wschodniej części budynku stał postawiony w niewielkiej odległości od jej muru stół - ołtarz chrześcijański. Jego kształt był zbliżony do litery „C”. Ołtarz znajdował się za zasłoną i był także zwrócony ku wschodowi. Z tego kierunku wspólnota oczekiwała ostatecznego przyjścia Pana - słońca sprawiedliwości ${ }^{25}$. Ale przytaczane dzieło Louisa Bouyera nic nie wspomina o krzyżu w przestrzeni tych kościołów.

Prace archeologiczne nie pomagają nam w odtworzeniu usytuowania ołtarzy, które zostały ofiarowane przez cesarza Konstantyna Wielkiego rzymskim bazylikom. Jak twierdzi współcześnie Sible de Blaauw: „Możemy tylko prezentować hipotezy co do ich ulokowania w zależności od gradacji elementów przeznaczonych do kultu"26. Ołtarz dla bazyliki św. Piotra na Watykanie był najokazalszy i najdroższy. Prawdopodobnie miał formę stołu i składał się z blatu z potrzebnymi wsparciami. Przedmiot ten wykonany $z$ drewna miał metalowe okrycie z pozłacanego srebra o wadze 106 kg z 400 różnokolorowymi gemmami. Okrycie to dekoro-

${ }^{23}$ Por. J. Mieczkowski, J. Superson, Teologiczne usytuowanie ołtarza w światyni chrześcijańskiej, „Collectanea Theologica” 78 (2008) nr 1, s. 114.

${ }^{24}$ L. Bouyer, Architektura i liturgia, tłum. P. Włodyga, Kraków 2009, s. 26.

${ }^{25}$ Por. tamże, s. 27-28, 31.

${ }^{26} \mathrm{~S}$. de Blaauw, L'altare nelle chiese di Roma come centro del culto e della committenza papale, [w:] Roma nell'alto Medioevo. Atti (Spoleto, 27 aprile-1 maggio 2000), t. 2, Spoleto 2001, s. 973 (Atti delle Settimane di studio del Centro italiano di studi sull'alto Medioevo, 48). 
wało każdą jego stronę. Chociaż ołtarze donacji Konstantyna nie były umocowane do podłoża i łatwo można je było przesunąć, to i tak miały wyznaczoną konkretną lokalizację. Złote farum cantarum w bazylice na Lateranie było zawieszone nad ołtarzem. Natomiast w bazylice św. Piotra najważniejsze ognisko światła odpowiadające farum przed ołtarzem było zawieszone i zarezerwowane dla indykacji grobu apostoła ${ }^{27}$. Jak podkreśla Sible de Blaauw, w tym kościele ołtarz był podporządkowany miejscu pochówku św. Piotra, nad którym był baldachim. Stąd prawdopodobnie w przestrzeni między baldachimem a grobem apostoła na podwyższonej platformie dla celebracji eucharystycznej ulokowano konstatyński ołtarz. Konstantyńskie ołtarze były upiększane różnymi precjozami z donacji Konstantyna i innych ofiarodawców, ale wśród nich nie było krzyża. Celebrans w czasie sprawowania Eucharystii przy takim ołtarzu był zwrócony ku wschodowi, co było równoznaczne ze zwróceniem się ku zebranym wiernym ${ }^{28}$.

Patrolog Fryderyk Van der Meer, badając dziedzictwo św. Augustyna, mówi, że w swojej bazylice biskup Augustyn celebrował przy ołtarzu w kształcie stołu z drewna małych rozmiarów, który był usytuowany w środku nawy kościoła ${ }^{29}$. Ołtarz był przykryty białym obrusem połyskującym złotem, na którym widniały imiona świętych męczenników (memoria), którzy tam spoczywali. Wierni stali wokół ołtarza, tworząc zgromadzenie rozszerzające swoje ramiona we wszystkich kierunkach. Punktem centralnym był mały stół. Ołtarz do momentu ofiarowania był pozbawiony świec, kwiatów - wyczekiwał ${ }^{30}$. Po ofiarowaniu jego mensa była zastawiona kielichem i paterami ze złota, na których kładziono chleby $^{31}$. Biskup, mając przed sobą tak przyszykowany ołtarz, wznosił ramiona i zwrócony twarzą ku wschodowi inicjował dialog prefacji ${ }^{32}$.

${ }^{27}$ Antoni Nowowiejski wspomina o papieżu Hadrianie I i o wykutym na jego polecenie farum w kształcie krzyża dla bazyliki św. Piotra, w którym mieściło się 1370 lamp - por. A. J. Nowowiejski, Wykład Liturgji Kościoła Katolickiego. O środkach rozwinięcia kultu, t. 1, cz. 1, Warszawa 1893, s. 513.

${ }^{28}$ Por. S. de Blaauw, L'altare nelle chiese di Roma, s. 970-973, 980.

${ }^{29}$ Por. F. Van der Meer, Sant'Agostino pastore d'anime, Roma 1971, s. 867 (Biblioteca di cultura religiosa. Seconda serie, 142).

${ }^{30}$ Por. tamże, s. 868.

${ }^{31}$ Por. tamże, s. 871.

${ }^{32}$ Por. tamże, s. 868, 870-872. 
Również i w spuściźnie literackiej Augustyna nie znajdujemy zapisów co do krzyża na ołtarzu.

Krzyż w chrześcijaństwie pojawił się w liturgii jerozolimskiej. Z zapisków Egerii, pątniczki do Ziemi Świętej z IV wieku, dowiadujemy się, że w Wielki Piątek przynoszono w srebrnej szkatule na Golgotę relikwie krzyża świętego, kładziono je na stole, na którym leżała lniana tkanina, po czym każdy chrześcijanin podchodził do krzyża i oddawał mu cześć czołem i oczami oraz składał na nim pocałunek ${ }^{33}$. Chociaż jerozolimski kościół miał relikwie krzyża, to krzyża nie umieszczał na ołtarzu.

Wraz z ustawianiem ołtarzy na środku nawy głównej (kościoły afrykańskie i bazyliki rzymskie) czy też w apsydzie (kościoły romańskie) ujednolicono orientację modlitw zanoszonych przez celebransa i wspólnotę. Prezbiter zwracał się ku wschodowi i wypowiadał modlitwy. Zazwyczaj na sklepieniu apsydy, pod którym znajdowała się katedra, był namalowany krzyż, Pantokrator czy inna figura Chrystusa. W kościołach romańskich i gotyckich ołtarz był w apsydzie, która znajdowała się po wschodniej stronie. Celebrans miał przed sobą ścianę apsydy, a na niej mozaikowy, namalowany lub zawieszony krzyż bez pasyjki. Czy wierni zebrani na Eucharystii modlili się w kierunku wschodnim? Z zachowanych rubryk z XVI wieku wynika, że prezbiter na słowa Dominus vobiscum miał zwrócić się ku zgromadzeniu. Natomiast jeśli sprawował przy tak usytuowanym ołtarzu, że już jakąś część wiernych miał przed sobą, wówczas nie obracał $\mathrm{się}^{34}$. Zarazem należy podkreślić za L. Bouyerem, że modlitwa kierowana ku wschodowi nie była przywilejem prezbitera, ale jeśli kościół posiadał ołtarz, „nazywany dziś ołtarzem «twarzą do ludzi», mogło się zdarzyć, że część wiernych - niekiedy nawet większość - była przez cały czas modlitwy eucharystycznej zwrócona plecami do ołtarza" ${ }^{35}$.

Ta liturgiczna zasada zanoszenia modlitw ku wschodowi została złamana z chwilą pojawienia się ołtarzy bocznych. Znikła wówczas także reguła: jedna Ofiara, jeden ołtarz, jedno zgromadzenie. Przy tych ołta-

${ }^{33}$ Por. Egeria. Pielgrzymka do miejsc świętych, tłum. P. Iwaszkiewicz, [w:] Do Ziemi Świętej. Najstarsze opisy pielgrzymek do Ziemi Świętej IV-VIII w., wybór, wstęp, wprowadzenia i opracowanie P. Iwaszkiewicz, Kraków 2010, s. 184-185.

${ }^{34}$ Por. L. Bouyer, Architektura i liturgia, dz. cyt., s. 51.

${ }^{35}$ Tamże, s. 52. 
rzach, które pojawiły się w Europie Zachodniej już od V wieku, kapłan celebrujący Najświętszą Ofiarę zanosił modlitwy w każdym kierunku ${ }^{36}$.

\section{Krzyż na ołtarzu}

Zanim postawiono na mensie ołtarza krzyż, w pierwszym tysiącleciu Kościoła posługiwano się następującymi krzyżami: krzyżami procesyjnymi, zawieszanymi na pergoli, wieńczącymi cyborium czy umieszczonymi pod ówczesnymi ogromnymi żyrandolami ${ }^{37}$. W Europie Zachodniej krzyż na mensie ołtarzowej pojawił się dopiero w XI wieku. W Polsce zwyczaj ten jest odnotowany w wieku XIII ${ }^{38}$.

Francuz Charles de Rohault de Fleury wyraża opinię, że księża, sprawując mszę świętą w XII i XIII wieku, chcieli mieć przed oczami relikwie krzyża, który sami przynosili na ołtarz, a po skończonej służbie zanosili do zakrystii ${ }^{39}$. Tę myśl podejmuje Antoni Nowowiejski i dodaje, że w ten sposób kapłan, patrząc na krzyż, miał przed swymi oczami głównego sprawcę ofiary ${ }^{40}$. Innego zdania jest Theodor Klauser, który twierdzi, że jako pierwsze po 1100 roku na ołtarzowej mensie zostały ustawione kandelabry, a dopiero w XIII wieku ustawiono na niej krzyż. Był to czas, kiedy rozpowszechniła się tajemnica męki. Zmiany zachodzące na mensie ołtarzowej, jak podkreśla niemiecki liturgista, dokonały się w czasach, gdy msza święta zaczynała być rozumiana jako czynność w dużej mierze oddana kapłanowi ${ }^{41}$. Zwyczaj stawiania krzyża na ołtarzu między kandelabrami uprawomocnił w swoim nauczaniu papież Innocenty III.

${ }^{36}$ Por. S. de Blaauw, Innovazioni nello spazio di culto fra basso medioevo e cinquecento: la perdita dell'orientamento liturgico e la liberazione della navata, [w:] Lo spazio e il culto. Relazioni tra edificio ecclesiale e uso liturgico dal XV al XVI secolo, a cura di J. Stabenow, Venezia 2006, s. 32.

${ }^{37}$ Por. A. J. Nowowiejski, Wykład Liturgji Kościoła Katolickiego, dz. cyt., t. 1, cz. 1, s. $1046-1055$.

${ }^{38}$ Por. W. Głowa, Krzyż ołtarzowy w Kościele w Polsce, [w:] Studia z dziejów liturgii w Polsce, red. M. Rechowicz, W. Schenk, Lublin 1973, s. 171, 181 (Towarzystwo Naukowe Katolickiego Uniwersytetu Lubelskiego. Rozprawy Wydziału Teologiczno-Kanonicznego, 33).

${ }^{39}$ Por. C. Rohault de Fleury, La Messe études archéologiques sur ses monuments, t. 5, Paris 1887, s. 139.

${ }^{40}$ Por. A. J. Nowowiejski, Wykład Liturgji Kościoła Katolickiego, dz. cyt., t. 1, cz. 1, s. 1057.

${ }^{41}$ Por. T. Klauser, La liturgia della Chiesa occidentale. Sintesi storica e riflessioni, TorinoLeumann 1971, s. 137-138. 
Dla papieża krzyż jest pośrednikiem - kamieniem węgielnym między dwoma zapalonymi kandelabrami symbolizującymi radość dwóch narodów z narodzin Chrystusa: judejskich pasterzy i magów ze Wschodu. Z tych dwóch narodów Chrystus uczynił jeden, a światło z kandelabra symbolizuje wiarę narodu ${ }^{42}$.

Krzyże ołtarzowe w pierwszym okresie miały wysokość około $50 \mathrm{~cm}$ wraz z podstawą, ale już od XIV wieku to spore krucyfiksy sporządzone ze srebra, złota czy kryształu, wysokie na ponad $1 \mathrm{~m}$. Stawianie krzyża na mensie ołtarzowej było oddolną inicjatywą celebransów zatwierdzoną przez potrydencki rytuał i rubrycele. Mimo to w XVI i XVII wieku w Italii próbowano powstrzymać rozwijający się proces stawiania krzyża bezpośrednio na ołtarzu ${ }^{43}$.

Kto zainicjował w chrześcijaństwie praktykę stawiania krzyża na ołtarzu?

Czy pobożni łacińscy prezbiterzy u początku drugiego tysiąclecia Kościoła byli inicjatorami stawiania krzyża na ołtarzu? Na początku XX wieku, gdy rozpoczęto badania liturgii metodą komparatywną, konwertyta Erik Peterson i Anton Baumstark po przeprowadzeniu odpowiednich badań stwierdzili, że w nestoriańskich opactwach w VI wieku na ołtarzu był lokowany krzyż, ku któremu zanoszono modlitwy ${ }^{44}$, równocześnie była to modlitwa zanoszona ku wschodowi. W swoim podręczniku Mario Righetti zaznacza, że zwyczaj ten nie przyjął się ani na Wschodzie, ani na Zachodzie ${ }^{45}$.

${ }^{42}$ Por. Innocenzo III, Il sacrosancto misterio dell'altare (De sacro altaris mysterio), a cura di S. Fioramonti, Città del Vaticano 2002, s. 132-133 (Monumenta Studia Instrumenta Liturgica, 15).

${ }^{43}$ Por. A. J. Nowowiejski, Wykład Liturgji Kościoła Katolickiego, dz. cyt., t. 1, cz. 1, s. $1056-1058$.

${ }^{44}$ Por. E. Peterson, La croce e la preghiera verso oriente, „Ephemerides liturgicae” 59 (1945), s. 56-57.

${ }^{45}$ Por. M. Righetti, Manuale di storia liturgica. Introduzione generale, t. 1, Milano 1955², S. 446. 
Papież Benedykt XIV

Pomimo zaleceń potrydenckich zawartych w rubrykach ksiąg liturgicznych wydaje się, że ustawianie krzyża na ołtarzowej mensie w czasie sprawowania Eucharystii nie było przez ogół prezbiterów rozumiane jako praktyka oczywista. Prawdopodobnie taka właśnie sytuacja przynagliła arcybiskupa Bolonii Prospera Lambertiniego do publikacji po włosku dzieła Del sacrificio della messa (O ofierze mszy świętej), w którym autor podkreślał, że celebruje się mszę świętą wyłącznie na ołtarzu, na którym jest ustawiony krzyż z figurą Jezusa ukrzyżowanego ${ }^{46}$. Ta biskupia wykładania po objęciu przez Prospera Lambertiniego Stolicy Piotrowej stała się podstawą konstytucji apostolskiej Accepimus praestantium Benedykta XIV.Papież zauważył w niej, że w wielu kościołach podległych jego jurysdykcji jako głowie Państwa Kościelnego w ołtarzach głównych przedstawia się świętego lub świętych. Ten fakt nie zwalnia prezbiterów sprawujących przy tych ołtarzach Eucharystię od umieszczania na mensie ołtarzowej krzyża. Zarazem Benedykt XIV przypomina świadomość wschodnich chrześcijan, którzy za drzwiami sanktuarium nad ołtarzem umieszczają krzyż i księgę Ewangelii. Zdaniem papieża dziedzictwo wschodnie, jak i tradycja zachodnia co do celebracji mszy świętej obligują do stawiania krzyża z wizerunkiem Ukrzyżowanego na mensie ołtarzowej między kandelabrami i tylko przy takim ołtarzu można sprawować Eucharystię ${ }^{47}$.

\section{Wiek XX}

Przedstawiciele ruchu liturgicznego w latach 20.XX wieku w Niemczech wprowadzili nowe usytuowanie ołtarza. Celem przesunięcia ołtarza ku środkowi nawy głównej było stworzenie jednorodnej przestrzeni. Ta nowa przestrzeń miała wyrażać ideę uformowanego, zjednoczonego

${ }^{46}$ Por. P. Lambertini (Benedetto XIV), Della santa messa. Trattato istruttivo, t. 1, Napoli 1836, s. 14

${ }^{47}$ Por. Benedictus Papa XIV, Accepimus praestantium, [w:], Sanctissimi Domini Nostri Benedicti papae XIV. Bullarium, tomus secundus, in quo continentur constitutiones, epistolae, aliaque edita $\mathrm{ab}$ anno MDCCXLVI. Usque ad totum annum MDCCXLVIII, editio nova, summo studio castigata, vol. 4, Mechliniae 1826, s. 264, 266, 272. 
Kościoła sprawującego mszalną ofiarę ${ }^{48}$. W ten sposób podkreślono doniosłość kapłaństwa powszechnego celebrującego Eucharystię wraz z kapłaństwem hierarchicznym. 6 sierpnia 1921 roku w krypcie w Maria Laach po raz pierwszy odprawiono mszę świętą w taki właśnie sposób. Zarazem była to msza święta komunijna, gdyż w czasie jej sprawowania rozdawano komunię świętą. Do tej pory w Maria Laach komunię świętą można było otrzymać tylko w czasie mszy sprawowanej na ołtarzu sa$\mathrm{kramentu}^{49}$. Wraz z przesunięciem ołtarza wprowadzono także procesję z darami, której wcześniej nie było.

Za przykładem Maria Laach inni prekursorzy odnowy liturgicznej (np. Romano Guardini, Pius Parsch) odsunęli ołtarz od ściany. W ten sposób rozpoczęła się epoka celebracji nazywanej versus populum, przede wszystkim w czasie mszy świętych z młodzieżą. Z ołtarzy odsuniętych od ściany zdjęto tabernakulum i przeniesiono je w inne miejsce. Josef Jungmann jako czołowy przedstawiciel ruchu liturgicznego i związanej z nim odnowy w 1961 roku podkreślał: „Cecha, która odróżnia chrześcijański ołtarz od prawie wszystkich struktur-ołtarzy w historii religii, wynika z tego, że znajduje się on w przestrzeni celebrującej wspólnoty [...]. Ołtarz więc musi być dobrze widoczny dla wszystkich. Niemniej jednak nie może być umieszczony jakby na scenie; przecież osoby zgromadzone wokół niego nie są zwykłymi obserwatorami" "50.

Oczywiście byli i ci, którzy w sposób krytyczny odnosili się do takiego usytuowania ołtarza. Klaus Gamber, wieloletni dyrektor Instytutu Liturgicznego w Ratyzbonie, zaznaczał, że przy tak ustawionym ołtarzu (nazywa go ołtarzem ludowym), celebrując versus populum, trudno mówić, że wierni mają się zwrócić ku Panu, przecież patrzą na siebie - ku drugiemu człowiekowi ${ }^{51}$.

${ }^{48}$ Por. K. Richter, Comunità, spazio liturgico e altare, [w:] L'altare mistero di presenza, opera dell'arte. Atti del II Convegno liturgico internazionale, Bose 31 ottobre-2 novembre 2003, a cura di G. Boselli, Magnano 2005, s. 187 (Litrugia e Vita).

${ }^{49}$ Por. tamże, s. 188.

${ }^{50}$ Cyt za: W. Zahner, Realizzazioni di altari in Germania e in Austria, [w:] L'altare mistero di presenza, dz. cyt., s. 128.

${ }^{51}$ Por. K. Gamber, Zwróćmy się ku Panu! Zagadnienia dotyczące budownictwa kościelnego i modlitwy zwróconej na wschód. Z przedmową kardynała Józefa Ratzingera oraz posłowiem o. Ludwika Bouyera zaczerpniętymi z wydania francuskiego, tłum. G. Kucharczyk, Poznań 1998, s. 65. 
Jeszcze zanim w Kościele powszechnym dojrzała idea kolejnego powszechnego soboru, Komisja Liturgiczna ustanowiona przy Konferencji Episkopatu Niemiec w 1949 roku wydała dokument zawierający wytyczne co do konfiguracji domu Bożego według ducha liturgii rzymskiej. Z punktu 8 wytycznych wynika, że byłoby niedobrze, gdyby bez poważnego powodu kościół nie był usytuowany na osi wschód-zachód. Równocześnie komisja dostrzegła także dochodzące z różnych środowisk głosy, aby w przyszłości celebrans i wierni byli zwróceni ku sobie, jako jedna wspólnota zebrana wokół ołtarza. Miało to być zgodne z tradycją stale zachowywaną w rzymskich bazylikach. „W chrześcijańskiej świątyni modlitwa ukierunkowana ku wschodowi znajduje swoje centrum odniesienia w ołtarzu, ku któremu wszakże muszą się zwrócić kapłan, jak i wspólnota"52.

\section{Refleksja przedsoborowa, odnowa soborowa}

\section{i aktualizacja posoborowa}

Zaprezentowana myśl ruchu liturgicznego co do usytuowania ołtarza i formy celebrowania przy nim została wzięta pod uwagę przez komisję przygotowująca tekst soborowej Konstytucji o liturgii świętej Sacrosanctum Concilium. Już 12 czerwca 1962 roku komisja przygotowawcza zaakceptowała tekst mówiący o zrewidowaniu kanonów i statutów odnoszących się między innymi do budowy i kształtu ołtarzy. Wraz z zaaprobowanym wówczas tekstem dołączono deklarację ilustrującą sposoby tejże rewizji, wśród których była forma celebracji mszy świętej versus populum. Rinaldo Falsini jako uczestnik prac w komisji soborowej dodaje, że całe zgromadzenie soborowe na sesji 31 października 1963 roku usłyszało od biskupa Carla Rossiego odpowiedzialnego za rozdział VII konstytucji jego relację, w której była także mowa o trudnościach, jakie przyszłe komisje posoborowe mogłyby mieć z wprowadzeniem poszczególnych punktów konstytucji w życie Kościoła. Biskup Carlo Rossi do swojej relacji dołączył czternastopunktową deklarację odnoszącą się do punktu 128 Konstytucji o liturgii świętej, w której jest mowa o usytuowaniu ołtarza już oddalonego od ściany w przestrzeni między prezbiterium a zgromadzonym ludem, jak również o zasadności celebracji versus populum także przy

${ }^{52}$ T. Klauser, La liturgia della Chiesa, dz. cyt., s. 215-216. 
ołtarzu, na którym byłoby ulokowane małych rozmiarów tabernakulum. Zgromadzeni wówczas ojcowie soborowi podczas głosowania wyrazili pełną aprobatę dla punktu 128 konstytucji ${ }^{33}$.

Przytoczone wyżej informacje Falsiniego przeczą tym wszystkim współczesnym głosom, a jest ich sporo, które propagują myśl, jakoby celebracja versus populum była „pomysłem” komisji posoborowych, a nie założeniem soborowym.

Po zatwierdzeniu Konstytucji o liturgii świętej consilium powołane do wprowadzenia jej założeń w życie Kościoła wraz z Kongregacją ds. Rytów ogłosiło 26 września 1964 roku instrukcję Inter oecumenici o należytym jej wykonywaniu. Było to więc jeszcze w czasie obrad soborowych. W punkcie 91 instrukcja mówi o ołtarzu: „Pożądane jest wystawienie oftarza wielkiego w takim oddaleniu od ściany, aby go łatwo można obejść i aby celebra mogła się odbywać twarzą do ludu; w świątyni zaś ołtarz powinien zająć takie miejsce, aby rzeczywiście stanowił ośrodek, na którym samorzutnie skupia się uwaga całego zgromadzenia wiernych". Natomiast punkt 94, w którym jest mowa o zdobieniu ołtarzy, przedstawia także miejsce dla krzyża: „Krzyż i świeczniki potrzebne na ołtarzu przy poszczególnych czynnościach liturgicznych można ustawić także obok ołtarza, za zgodą miejscowego ordynariusza" ${ }^{54}$. Jak łatwo dostrzec, oba te punkty rewidują przedsoborową myśl co do ołtarza i krzyża na nim. To w gestii biskupa miejsca było ustalenie miejsca dla krzyża.

Pierre Jounel w swoim komentarzu do tej instrukcji wypowiedział się w bardzo sugestywny sposób: „Także Sobór dołączył do tej odnowy. Każdego poranka podczas jego obrad sprawowała się Msza św. zwrócona ku auli soborowej, natomiast podczas Soboru Watykańskiego I celebrans obracał się plecami do ojców"55.

Samo wykonanie punktu 94 instrukcji Inter oecumenici prawdopodobnie sprawiało w Kościele wiele kłopotów. Dlatego organ consilium czasopismo „Notitiae” w tekście Dubia z 1966 roku podaje trzy możliwości umieszczenia krzyża poza ołtarzem:1) umieszczenie krzyża procesyjnego przed ołtarzem zwróconego ku celebransowi, co nie zawsze dobrze

${ }_{53}$ Por. R. Falsini, Celebrare e vivere il mistero eucaristico, a cura di M. Susini, Bologna 2009, s. 140-143 (Studi e Ricerche di Litrurgia).

${ }^{54}$ http://www.kkbids.episkopat.pl/dokumentypovii/inter/5.htm (28 IV 2011).

${ }^{55}$ Cyt za: R. Falsini, Celebrare e vivere, dz. cyt., s. 144. 
koresponduje z innymi elementami prezbiterium; 2) umieszczenie dużego krzyża zwisającego z wysoka; 3) umieszczenie krzyża na ścianie absydy. W dwóch ostatnich przypadkach nie ma potrzeby umieszczać drugiego krzyża na ołtarzu ${ }^{56}$. Ustalenia te sprawiły, że w 1970 roku Institutio Generalis Missalis Romani podaje tylko ogólną zasadę znaną już z instrukcji Inter oecumenici, że krzyż ma być ustawiony na ołtarzu lub obok niego i ma być dobrze widoczny dla zgromadzonych ${ }^{57}$.

Trudno jest jednoznacznie wskazać historyczną przyczynę pojawienia się w 1994 roku pewnego tekstu na łamach „Notitiae”, wówczas już organu Kongregacji ds. Kultu Bożego i Dyscypliny Sakramentów. W tekście tym zawarta jest między innymi myśl: „Usytuowanie ołtarza versus populum przez obecne prawodawstwo liturgiczne jest elementem bardzo dobrze widzianym, ale mimo wszystko nie jest to walor absolutny, przewyższający każdy inny. [...] Pryncypium jedyności ołtarza jest teologicznie najważniejsze, ważniejsze niż praktyka celebracji zwróconej ku ludowi”58. A co do samego sformułowania „ "Celebracja zwrócona ku ludowi» nie ma sensu teologicznego, ale topograficzno-pozycjonalne. Każda celebracja Eucharystii jest ad laudem et gloriam nominis Dei, ad utilitatem quoque nostram, totiusque Ecclesiae suae sanctae. Teologicznie zatem msza jest zawsze zwrócona ku Bogu i zwrócona ku ludowi. W formie celebrowania należy być uważnym, aby nie zamieniać teologii i topografii, przede wszystkim wówczas, kiedy kapłan jest przy ołtarzu. Tylko podczas dialogów od ołtarza kapłan mówi do ludu. Cała reszta jest modlitwą do Ojca przez Chrystusa w Duchu Świętym. Ta teologia musi być widzialna" ${ }^{2}$.

\section{Zakończenie}

Pierwsze dziesięciolecie trzeciego tysiąclecia Kościoła na nowo objawia, że ciągle trwa w nim żywa dyskusja nad ołtarzem, krzyżem i orientacją modlitw artykułowanych podczas sprawowanej Eucharystii. Dyskusja

\footnotetext{
${ }^{56}$ Por. Documentorum explanatio. Dubia, "Notitiae" 2 (1966) nr 7, s. 290-291.

${ }^{57}$ Por. Missale Romanum ex decreto Sacrosancti Oecumenici Concilii Vaticani II instauratym auctoritate Pauli PP. VI promulgatum. Editio typica, Typis Polyglottis Vaticanis 1970, s. 77.

${ }^{58}$ Pregare „ad orientem versus”, “Notitiae” 29 (1993) nr 5, s. 249.

${ }^{59}$ Tamże.
} 
ta została zainspirowana przez samego Josepha Ratzingera wskazaną już publikacją Duch liturgii. Sam autor książki jako papież Benedykt XVI, celebrując Eucharystię, podkreśla, że obecność krzyża na ołtarzu, oprócz tego, że ma zasadniczy i fundamentalny walor teologiczny, jest punktem odniesienia dla wzroku sprawującego Eucharystię, jak i dla oczu wszystkich uczestniczących w tej celebracji. Tak umieszczony krzyż jednoczy wszystkie spojrzenia ${ }^{60}$. Można spuentować, że wówczas punkt odniesienia jest punktem orientacji. Za tak umieszczonym krzyżem na ołtarzu opowiadają się Nicola Bux ${ }^{61}$ czy Guido Marini: „Usytuowanie krzyża w centrum ołtarza wskazuje na centralność ukrzyżowania w celebracji eucharystycznej i właściwe ukierunkowanie, które całe zgromadzenie jest wezwane zachować podczas liturgii eucharystycznej: nie patrzymy na siebie nawzajem, ale patrzymy na tego Zbawiciela, który narodził się, umarł i zmartwychwstał dla nas"62.

Oglądając papieskie celebracje, można dostrzec, że krzyż zasłania zgromadzeniu widok na dary złożone na ołtarzu, osobę przewodniczącego celebracji, jak i postacie eucharystyczne. Czy umieszczony na ołtarzu wysoki krzyż nie przysłania obecności Chrystusa w osobie celebrującego i tej nadzwyczajnej - pod postaciami eucharystycznymi (por. konst. Sacrosanctum Concilium, 7)? Świeca paschalna przypisana ambonie nie zasłania tego, kto proklamuje dobrą nowinę. Czy nie należy podjąć refleksji nad krzyżem i ołtarzem zgodnej z propozycją emerytowanego profesora Instytutu Liturgicznego św. Anzelma w Rzymie Matiasa Augé, i zawiesić krzyż nad ołtarzem ${ }^{63}$ ? Wówczas ten chrześcijański znak z wizerunkiem ukrzyżowanego Jezusa Chrystusa będzie nieustannym punktem odniesienia - „chorągwią zwycięstwa” Górującego nad i Wzywającego ku - punktem pośredniczącym między liturgią na ołtarzu ziemskim i na ołtarzu w niebiosach. Ukrzyżowany, a zarazem intronizowany na krzyżu Jezus Chrystus prezentowałby się wówczas jako ten, który ciągle

${ }^{60}$ Por. J. Ratzinger, Teologia della liturgia. La fondazione sacramentale dell'esistenza cristiana, Città del Vaticano 2010, s. 536 (Opera omnia, 11).

${ }^{61}$ Por. N. Bux, La riforma di Benedetto XVI. La liturgia tra innovazione e tradizione, prefazione di V. Messori, Casale Monferrato 2008, s. 101.

${ }^{62}$ Il maestro delle Celebrazioni sui riti presieduti dal Papa. „L'«oggi» del Natale”, „L'Osservatore Romano" 24-25 dicembre 2007, s. 8.

${ }^{63}$ Por. http://liturgia-opus-trinitatis.over-blog.it/article-mensa-ara-croce-o-mensa-ara-la-croce-65581056.html (5 IV 2011). 
panuje nad światem i nieustannie obwieszcza swoje decyzje dotyczące życia ziemskiego i wiecznego.

Kraków

JAROSEAW A. SUPERSON SAC

\section{Słowa kluczowe}

Krzyż, ołtarz, orientacja w czasie modlitwy

\section{Summary}

\section{Cross - altar - orientation of the offered prayer}

This article presents a brief history of the orientation of the altar in the liturgical space, the cross with the image of the Crucified on it and the direction of the liturgical prayers from the altar. In the Church's history the altar was usually placed in the apse or among the congregation. For hundreds of years there was a rule that the celebrant standing at the altar and the faithful participating in the Mass offered prayers to eastern direction. In the first millennium at the Roman Catholic Church only consecration gifts were being placed on the altar, and only at the beginning of the second millennium first the candelabra, than the crucifix were put on. After accepting the Dialogue Mass and the versus populum celebration by the Second Vatican Council, the cross was placed near the altar usually as the processional cross with the image of Jesus Christ facing the faithful. Since 2007, during the celebration of the Eucharist presided by Pope Benedict XVI the cross stands in the center of the altar with the image of the Crucified directed towards the principal celebrant.

\section{Keywords}

The cross, the altar, the orientation of prayer 